\title{
"There should be a room for self-initiated activity" A narrative inquiry on my teaching practices
}

\author{
Hanung Triyoko \\ English Department of Educational Faculty \\ State Islamic Studies Institute (STAIN) Salatiga \\ Jl. Tentara Pelajar No. 02 Salatiga, Central Java, Indonesia \\ hanungina@yahoo.co.id
}

\begin{abstract}
This paper is my endeavour to shorten the gap between the realities in my own teaching practices and those practices presented in books and research reports as effective English teaching. In this paper, through narrative inquiry method of writing, I will refer to my experiences to show my way of knowing as well as my way of writing the specific contexts of my teaching of English. Here and then, I may show my subjectivity upon certain issues in the English teaching-learning process but I do this to enable myself go deeper to my personal values. Nonetheless, for the betterment of my classroom practices specifically and the teaching of English for Islamic studies in Indonesia, in general, my inquiry on my own professional practices and the insights on how I should see and make some changes in my teaching as specified by the AAA perspective discussed in details will become a very good start.
\end{abstract}

Keywords: Self-Initiated Activity, Narrative Inquiry, AAA Perspective

\begin{abstract}
Abstrak
Tulisan ini adalah upaya saya untuk memperkecil kesenjangan antara kenyataan di praktek mengajar saya sendiri dengan praktek yang ada di buku dan laporan penelitian seperti mengajar bahasa Inggris secara efektif. Saya akan merujuk ke pengalamanku untuk memperlihatkan cara saya mengetahui dan juga cara saya menulis konteks khusus dari pengajaran bahasa Inggrisku. Di sini dan selanjutnya, saya mungkin menunjukkan subyektivitasku terhadap masalah tertentu terhadap proses belajar mengajar bahasa Inggris tapi saya melakukannya untuk memudahkan saya sendiri mendalami nilai-nilai kepribadian saya. Meskipun demikian, demi kebaikan praktek kelas mengajar saya khususnya, dan untuk pengajaran bahasa Inggris untuk Perguruan
\end{abstract}


Tinggi Islam di Indonesia, secra umum, pertanyaan saya terhadap praktek profesi saya sendiri dan wawasan tentang bagaimana saya harus melihat dan membuat perubahan di dalam pengajaran saya yang telah dikemukakan oleh pandangan AAA yang akan dijelaskan secara rinci, akan menjadi permulaan yang bagus.

Kata Kunci: Kegiatan Inisiasi Diri, Pertanyaan Narasi, Perspektif AAA

\section{Introduction}

As a non-native English Teachers (NNET) involved in the teaching of English as a foreign language for Islamic Studies in Schools in Indonesia, I find myself perplexed with the rapid changing of the pedagogical as well the content knowledge of English teaching. English for Islamic studies is part of the teaching of English for specific purposes in the context of English Curriculum at the Islamic university in Indonesia. The main goals of the curriculum are to upgrade students' skills in understanding discourses in English on any issues related to Islam and in using English to convey the teaching of Islam and to represent their being Moslem. This paper however will not elaborate on the content of curriculum, rather on the approach, methods, problems and solutions resulted from the writer's reflection on his own teaching practices. According to Vally (1997: 70) teachers can "look back on events, make judgements about them, and alter their teaching behaviours in light of craft, research, and ethical knowledge" in order to improve his or her own teaching.

This paper is my endeavour to shorten the gap between the realities in my own teaching practices and those practices presented in books and research reports as effective English teaching. Instead of looking outside to the recommended practices in other classrooms and to characteristics of effective teaching performed by other teachers, I will start by looking inside 
of me and of my own classroom to ensure that I have the full explanation to the dynamic of my professional practices. Farrel, Thomas R.C. (2008: 4) says "reflective practice occurs when teachers consciously take on the role of a reflective practitioner, subject their own beliefs about teaching and learning to critical analysis, take full responsibility for their actions in the classroom, and continue to improve their teaching practice". Cadman (2008), Hewson (2007), Tripp (1998), and Reed-Danahey (1997) have ascertained in some extent that it is necessary for teachers to reflect on their own practices and to adopt narrative inquiry in order to finds solutions to their context-specific problems.

\section{Discussion}

\section{Narrative inquiry}

According to Reed-Danahey (1997: 9), the teacher doing the narrative methodology does not present his/her perceptions and feelings in isolation but locate them in the contexts. In this paper, I will refer to my experiences to show my way of knowing as well as my way of writing the specific contexts of my teaching of English. This kind of writing is called by Alvermann (2000 in Hewson, 2007: i) as narrative inquiry. Here and then, I may show my subjectivity upon certain issues in the English teaching-learning process but I do this to enable myself go deeper to my personal values. Indeed, subjectivity is the benefit of doing the narrative inquiry and is not separable from the realities of being a researcher (Hewson, 2007: 31). Furthermore, according to Cadmann (2008: 30) through analysing my own reflections upon my own contexts, I can give another example of process taken by an English teacher to personalize the continuous demand of professional development. Since I find a book written by Leo Van Lier 'Interaction in the Language Curriculum; Awareness, autonomy, and authenticity' as an appropriate 
framework to look into my current teaching contexts, I use Lier's theoretical perspective and refer to many of his conceptions of language learning to illustrate how I may make changes to my professional practices.

\section{I taught English the way I learnt it}

I was convinced by what my parent said about the advantages of being able to master English when I knew that my first English teacher was a very respectable rich woman. Since then, I was highly motivated to learn English. For many years, the most dominant motivation for Indonesian students to learn English was to obtain well-paid job (Bradford, 2007: 113). The very first thing I could show to other that I was good in English was to master all the rules of English structures. I learnt English structures from pieces to pieces, from simple to complex structures. Generally, I was exposed to reading texts or dialogues in written form where particular structures of English used and then I should answer some reading comprehension questions that forced me to exercise my translation skills and to write few paragraphs on some topics recommended that also required me to utilize the introduced structures. Learning English this way, I developed gradually my reading and my writing skills so when I was at university, I had developed the skills to appreciate and translate English classic novels, poems, and drama into bahasa, my mother tongue. My listening and speaking skills were developed outside schools. I loved paying attention to the lyrics of many Western songs as well as to listen to English radio broadcasting. I also joined an English course run by a private for profit institution that facilitated me to develop my speaking ability through occasionally involved in conversations with native speakers assigned in the institution and very often with my peers who were also motivated to use their English. Students' involvement in 
English course outside school, according to Dubin and Olsthain (1986: 30), can be one indicator of a failure in the teaching English at schools.

I often taught more than six classes every semester since I was first appointed as a teaching staff at Salatiga State Institute for Islamic Studies (STAIN Salatiga), Indonesia. I was too busy ensuring that I had covered up all the prescribed curriculum and materials of each subject I taught. The easiest way for me to look into my teaching performance was to look at my students' achievement, resulted from summative assessment in the form of tests in the middle and the end of semester.

Thank to the opportunity I have to pursue a higher study in Australia that now I have been off from any teaching routines for two years. Only now, I can see quite clearly that I taught my student English the way I learnt it. The prescribed curriculum to teach English for Islamic Studies in my University used framework similar to the curriculum framework of my school age English, in which the speaking and listening were given very little emphasise. The belief that students learnt English as a means to involve in global academic discourse dominated by English speaking countries was still dominant that the few authoritative people designing the curriculum focused on developing students reading and writing skills. The textbook English for Islamic Studies written by Djamaludin Darwis recommended as the main source provided many reading passages about the teaching of Islam and the social and historical aspect of Moslem communities in Indonesia and all those reading were there to introduce students to certain discrete English structures. The author sequenced each chapter of the book in this order: reading passages, reading comprehension questions, language focus, glossary, and writing task. The way I learnt English, the prescribed curriculum and the recommended textbook, and the excessive workload had altogether led me to teach English the way I learnt it. My classroom activities 
forced students to master English structures and I provided very little opportunity for them to use their English in real communication.

The contexts of my teaching differ to the contexts of teaching when I learnt English. Even though English is still considered as foreign language taught in schools, students nowadays have more opportunities to use their English outside schools. There are more English-speaking expatriates and tourists in Indonesia and more access to internet where students may involve in authentic communication with English users. Through the internet, students get many chances to use their English to communicate with any people, not necessarily native speakers, in any part of the world. Furthermore, my students may be motivated to learn English for enormous reasons different to mine described above. To initiate some changes to my teaching practices I certainly need to consider influential factors in teaching and learning such as context, curriculum and materials, students' treats, and assessment. The following section is how I look at those factors by using the Lier's theoretical perspective of Language teaching and learning.

\section{The AAA curriculum as a framework to look upon my teaching contexts} and to initiate some changes in my teaching practices.

In his book 'Interaction in the Language Curriculum; Awareness, autonomy, and authenticity', Leo van Lier builds his arguments on the English teaching-learning process upon the admition that there are always some constraints in the teaching- learning setting but there are also some sources and that sometimes actions intended to help can turn to control students' learning (1996: 7-8). Teachers are required to distinguish between constraints inseparable to the teaching-learning setting or the intrinsic constraints and those perceived to be constraints due to enforcement of 
certain system adopted by the institution or the artificial constraints (Lier, 1996: 8). To use my teaching contexts as an example, I have to know whether the prescribed curriculum, the recommended textbook, and the excessive workload are parts of the intrinsic or the artificial constraints. When I am sure that these constraints are artificial then I can appropriately cope with them. Teachers also need to be aware of the implications of activities in the classrooms in order to avoid misfit between the purposes and the procedures to achieve them. In my case, students' activities built around the unauthentic texts that contain chunks of English carefully chosen to help them learn English may control students' creativity and eventually slow down the pace of their learning. Bernaus and Gardner (2008: 388) assert that class anxiety increases and students motivation intensity decrease when the teacher is perceived as controlling.

\section{Curriculum and syllabus}

Curriculum is a journey to particular destination and syllabus is a guide to that destination. Curriculum may be more or less clearly described but syllabus must be sensitive to constraints and sources specific to the institution where learning takes place (Lier, 1996: 21). According to Lier (1996: 29), curriculum should be open to teachers' dimension of practices rather than that of the higher authority. Therefore, curriculum can also be seen as the teachers' theory of practice to transform their professionalism from an authority-based into a research-based one. Unless I see myself as having the choices to modify the prescribed curriculum in my university, my endeavour to reflect on my own teaching practices will not be off any value to my professionalism. The obvious problem for me implementing the prescribed curriculum is that very often I feel I do not own the curriculum, a feeling commonly shared by teachers in this situation (El-Okda, 2005: 36). 
To follow blatantly all sequences of my classroom activities as prescribed in the textbook also means to ignore the function of syllabus in Lier's perspective because syllabus, like a map, does not control the distance and the speed of someone's journey but to provide options and panoramas to be explored (Lier, 1996: 20-22). The learning tasks planned in the syllabus shall promote the self-actualization of every learner and that the performance required doing the task is adjustable to local constraints and sources (Lier, 1996: 206). Lier (1996: 208) suggests that textbook is only one strand among many other strands in the course. Using Lier's conceptions on the curriculum and the syllabus, the opportunity to adjust my classroom activities on the spot is always open since one of the characteristics of a good syllabus is its ability to balance between planned and improvised elements, and between stability and variety (Lier, 1996: 204). Hence, I can also let my students bring their own materials or choose their own preferred learning activities while at the same time direct them to the purposes of their learning. Besides, if we see learning materials as text, the designing of text is always shifting, it involves interactional process, and is being determined by the context (Derewianka, 2003: 141). I shall not worry to provide similar materials, in kind and amount, to every class I teach, since students will also play more roles in the realization of the syllabus. Consequently, I have to vary the assessment in order to address the specificity of each class. In the next paragraphs to follow, I will discuss why and how I may adopt Lier's conception on assessment in language learning.

\section{Awareness, autonomy, and authenticity}

Awareness, autonomy, and authenticity in language learning must be seen as interconnected, in which each necessitates and influences the present of other. In order to learn a language, one must be in the state of awareness or 
the condition when s/he is being aware that her or his experience to new learning is connected to her or his existing knowledge (Lier, 1996: 12). To explain this conception of awareness simply, let me use an anecdote. I liked singing a Japanese song ‘kokoronotomo' but I could not say I was involved in any activities of learning Japanese language. I might learn something else from my singing of that song but I might not learn at all about Japanese language. This situation changed though when I met a friend from Japan and started talking about the song and so I learnt little Japanese from that song.

Autonomy means the present of choices and the acceptance of responsibilities for every language learner to develop their own sense of direction in learning language (Lier, 1996: 19). Smith argues that making students autonomous in the learning is a cross-culturally valid pedagogical goal (2008: 396). I learnt very little thing about the Japanese language even though I liked singing 'kokoronotomo' because I did not have sense of direction of what I might do next with my Japanese.

Authenticity in Lier's perspective goes beyond the discussion of authentic materials and authentic tasks. Lier (1996: 128) says authenticity is the result of validation of classroom events and language by students and teacher and the endorsement of the relevance of things said and done, and of the ways in which they are said and done. Authenticity is more about action performed in class and cannot automatically be aroused from authentic materials therefore Lier (1996: 136) questions the uncritical preference upon authentic materials than materials audience-designed for classroom learners. An authentic action is intrinsically motivated and it is the realization of free choices and the expression of what a person feels and believes (Lier, 1996: 13). Helping students create their own vision of ideal L2 learners can be the first step to foster students intrinsic motivation (Dornyei, 2009: 33). One advantage of teaching English for Islamic studies to Moslem students is 
offcourse the absence of any disconformities regarding the content of the textbook with what my students believe as Moslem. However, obliging students do all the planned learning tasks in the textbook will diminish the potential of students taking authentic action.

Taking the AAA perspective above into considerations, the best thing that a teacher may do is to encourage and guide learning since a teacher can never cause or force learning (Lier, 1996: 12). Specific to language learning, Lier (1996: 35) advices teachers lay emphasis on facilitating access to language, knowledge, and skill, than to simplify tasks, in order to assist students' learning. When rich variety of exposure to language is provided, the awareness, autonomy, and authenticity perspective will likely assist students learning. Nevertheless, teachers cannot just bring to the classroom all language resources since the language exposed to students is usable when the learner can make sense of it, is receptive to it and makes an effort to process it (Lier, 1996: 45). The role of the teachers in this sense is like providing temporary support in Vigotsky's concept of Zone of Proximal Development (ZPD). However, teachers should maintain that the help from the teacher as the more competent other does not lead to external control since internal control of the learner is the prerequisite of the AAA perspective of language learning (Lier, 1996: 117).

\section{Interaction and conversation}

Lier (1996: 5) emphasizes on the quality of interaction in the language learning as to ensure that no forms of interactions lead to superficial communication or even pseudo communication. For Lier, interaction is the most visible manifestation of learning processes at work, in the classroom, although inner speech may well be equally crucial (Lier, 1996: 35). The conception of interaction in Lier's perspective necessitates the present of 
conversation between two people or between a person and his or her inner self, in case of inner speech.

Furthermore, Lier (1996: 54) says conversation as part of social interaction is the basic environment for the processing of language. To depend heavily on the sequences of activities, or the unit of analysis presented in the handbooks, especially when the handbook provides little chances for students to involve in social interaction among them or to have conversations between them means to deny students the basic environment for language learning. I can see now that my frequent involvement in conversations when I joined English course outside schools really compensated the lack of interactions in my schools. This is probably one of the reasons that quite a few students in my classrooms have the confidence to speak in English even though they have sufficient skills to read and write in English. If I had known that students themselves could organize the conversations and they did not have to stick to the planned activities in the textbook, I would have provided more peer conversations in my classrooms. Besides, conversation needs to be locally assembled rather than to be planned since it has its own dynamic (Lier, 1996: 168).

\section{Assessment and motivation}

Assessment correlates in various degrees to student motivation in learning either positively or negatively. The effects of assessment may impinge on more stakeholders, rather than just our students and may impose in students learning longer than what teachers may expect. Lier (1996: 16) provides some guidance for teachers to reduce the unexpected effects of doing assessment. Teacher must prioritize:

1. Personal considerations upon political and institutional ones

2. Self-knowledge upon evaluation by others 


\section{Intrinsic upon extrinsic motivation}

4. Self-assessment upon institutional assessment

Looking back to what I had done in assessing my students learning, none of the above priorities was present. I kept trying to teach by the textbook and assessed my students' achievement based on similar type and items of tests. I did not know that all my students might achieve more, even to their highest potential, if I never assigned similar type and items of test and I involved students in the assessment process instead, from the very beginning. Lier (1996: 119) argues that by letting students involved in the assessment process, students will feel that any feedbacks as the results of the assessment make sense because they belong to the process.

Bureaucratic demands and practices, external controls in the form of tests and grades may motivate students in learning, in the sense that students will work hard to achieve the standards and to feel success when they make it, but according to Lier (1996: 121), this is just 'surrogate motivation' and it will hinder authenticity. This is in accordance to McDonough's claim that learners developing effective motivational thinking maximize their own resources than count on externally imposed structures and strategy (McDonough, 2007: 369). A common problem faced by teachers is the perceived conflict between fulfilling their personal security and satisfying pedagogical needs of students (Pachler, Barnes, \& Field, 2009: 44). The four prioritises above, I think, can balance both teacher's and students' need therefore, help teachers solve this problem.

\section{Principles to follow}

One of the goals listed in the prescribed curriculum in teaching English for Islamic studies is to develop Moslem speakers and writers who will take advantages of their mastery of English to represent the noble virtues 
of Islam and the identity of Indonesian Moslem. The pedagogical practices facilitating the achievement of this goal allow students to become themselves through the language they are learning (Ushioda, 2009: 223). This particular goal can also be an example of what Jenkins (2006:174) argues as prioritizing intelligibility than conformity in becoming successful English users because students will become themselves as the representations of Moslem community rather then immerge in new cultural identities.

Furthermore, at the present teachers face a challenge to shift their teaching from system-based and form-based to language use and meaning orientation (Byrnes, 2002: 420). In doing this shift, Freeman and Freeman (1998: 80) suggest teachers embed the linguistics elements of communication in a rich non-linguistics context. Rather than starting with introducing a discrete language form, I can describe particular situation where students will use their English to communicate something about them as Moslem. In setting the scene for students to use their English in real communication, I may use students L1 to make sure that students can connect their new learning with their existing knowledge. I may also use the downward technique, in which teachers establish what students might already know about the topic and build their comprehension on the text from that point onward (Mangubhai, 2005: 205).

To use Lier's AAA perspective in language teaching and learning, I suggest that this can be achieved only if students are treated as having their own social and historical dynamics and every student is treated as individual. Addressing feeling of individual in any classrooms is as important as addressing the cognitive aspects of the individuals (Ellis, 2008: 22). Anxiety in language learning will decrease too when students feel comfortable to discuss about themselves and their feeling (Underwood, 1984: 17). I am aware now that my students have more variety in terms of motivations, 
resources, strategies, tools, and purposes that influence their learning of English. Below are some principles that I will follow to initiate changes in my teaching practices:

1. To reflect more in order to create a room for self-initiated activity that balance the intrinsic and extrinsic constraints and resources.

2. To place curriculum as a journey and syllabus as a map, not an end in itself, therefore I can deal with the prescribed curriculum and syllabus as describing destinations and directions so that my students and I always have choices regarding the ways and the speed of our learning journey.

3. To use textbook as one among many resources available to learn English and to allow students have their own learning materials to ensure the present of awareness, autonomy, and authenticity in my classrooms.

4. To expose students to variety of language forms and usage, not merely focus on structures, and to play role as a more competent other to let students pick what they need but at the same time place them on their ZPD.

5. To practice assessment that is sensitive to students' need of selfactualization, self-determination, personal investment, and optimal experience.

6. To promote students' internal control of their learning and to avoid fake motivations.

\section{Conclusion}

There are offcourse some practical things to elaborate further on how I can actually adopt the AAA perspective of language teaching learning to my classrooms of English for Islamic studies in Indonesia, which education system is characterised by its hierarchical decision making process. 
Nonetheless, for the betterment of my classroom practices specifically and the teaching of English for Islamic studies in Indonesia, in general, my inquiry on my own professional practices and the insights on how I should see and make some changes in my teaching as specified by the AAA perspective discussed above, I am sure, will become a very good start.

\section{References}

Bernaus, M., \& Gardner, R. C. (2008). Teacher Motivation Strategies, Student Perceptions, Student Motivation, and English Achievement. The Modern Language Journal, 92(3), 387-401.

Bradford, A. (2007). Motivational Orientations in Under-researched FLL Contexts: Findings from Indonesia. RELC Journal, 38(3), 302-323.

Byrnes, H. (2002). The role of task and task-based assessment in a contentoriented collegiate foreign language curriculum. English Language Testing Journal, 19(4), 419-437.

Cadman, K. (2008). From Correcting to Connecting: A personal story of changing priorities in teaching English as an Additional Language. TESOL in Context, 17(2), 29-37.

Derewianka, B. (2003). Trends and Issues in Genre-Base Approach. RELC Journal, 34(2), 133-154.

Dornyei, Z. (2009). The L2 Motivational Self System. In Z. Dornyei \& E. Ushioda (Eds.), Motivation, Language Identity and the L2 Self (pp. 942). Bristol: Multilingual Matters.

Dubin, F., \& Olshtain, E. (1986). Course Design: Developing Program and Materials for Language Learning. Cambridge: Cambridge University Press.

El-Okda, M. (2005). A Proposed Model for EFL Teacher Involvement in Ongoing Curriculum Development. The Asian EFL Journal Quarterly, 7(4), 33-49.

Ellis, R. (2008). Learner Beliefs and Language Learning. Asian EFL Journal Quaterly, 10(4), 7-25. 
Farrel, Thomas S.C. (2008) Reflective Practice in the Professional Development of Teachers of Adult Language Learners. CAELA Network Brief.

Freeman, Y. S., \& Freeman, D. E. (1998). ESL/EFL Teaching: principles for success. Portsmouth: Heinemann.

Hewson, S. (2007). 'Researchers know thyself'. Critical reflection on a teacher's research journey: If I had know then... TESOL in Context, $16(2), 25-32$.

Lamb, M. (2009). Situating the L2 Self: Two Indonesian School Learners of English. In Z. Dornyei \& E. Ushioda (Eds.), Motivation, Language Identity and the L2 Self (pp. 229-247). Bristol: Multilingual Matters.

Lier, L. v. (1996). Interaction in the Language Curriculum; Awareness, autonomy, and authenticity. New York: Longman Group Ltd.

Mangubhai, F. (2005). What can EFL Teachers Learn from Immersion Language Teaching? Asian EFL Journal Quarterly, 7(4), 203-212.

McDonough, S. (2007). Motivation in ELT. ELT Journal, 61(4), 369-371.

Pachler, N., Barnes, A., \& Field, K. (2009). Learning to Teach Modern Foreign Languages in the Secondary School (3 ed.). New York: Routledge.

Reed-Danahey, D. E. (1997). Auto/Ethnography: Rewriting the Self and the Social. Oxford, UK: Oxford International Publisher.

Smith, R. (2008). Learner Autonomy. ELT Journal, 62(4), 395-398.

Tripp, D. (1998). Critical Incidents in Action Inquiry. In G. Shacklock \& J. Smith (Eds.), Being Reflexive in Critical Educational and Social Research (pp. 36-49). London: Falmer.

Underwood, J. H. (1984). Linguistics Computers and the Language Teacher; A Communicative Approach Massachusetts: Newburry House Publisher, Inc.

Ushioda, E. (2009). A Person-in-context Relational View of Emergent Motivation, Self and Identity. In Z. Dornyei \& E. Ushioda (Eds.), Motivation, Language Identity and the L2 Self (pp. 215-228). Bristol: Multilungual Matters.

Vally, L. (1997). Listening to Other Voices: A description of teacher reflection in the United Stated. Peabody Journal of Education, 72(1), $67-88$ 